「医工連携がもたらす重度侵襲病態治療の最前線と近未来の治療」

\title{
REBOA による出血性ショック治療の最前線
}

藤田 健亮, 小倉 崇以

REBOA, 出血性ショック, P-REBOA

\section{Iはじめに}

Resuscitative endovascular balloon occlusion of the aorta（REBOA）は，外傷性ショックに対する resuscitative tool として主に救急医療領域で使用さ れ，また国内では intra-aortic balloon occlusion （IABO）という名称で，古くから親しまれていた。 循環動態不安定な外傷に対して, 蘇生的開胸術（Resuscitative thoracotomy；RT）の代替としてされる ことが多かったが，現在その適応が広がっている。 早期の REBOA 導入は，一時止血もしくは出血量の コントロールが可能となり, 脳や冠動脈への血流を 保ちながら definitive 治療へつなぐことができる. また，外傷以外にも大動脈瘤破裂，消化管出血，産 後出血, 子宮破裂や腫瘍切除, 後腹膜出血など非外 傷性疾患の出血コントロールにも有用である ${ }^{21)}$ 。ま た，挿入時や管理中の合併症を軽減するためのテク ニックも進歩し，今後 REBOA は場所や疾患を問わ ず，幅広い分野で活用されることが期待される。

\section{REBOA の進歩}

世界を見渡すと，さまざまな occlusion balloon が 存在する. balloon（カテーテルのシャフト）のサ イズにより，用いるシースのサイズも異なる。本邦 では, BLOCK BALLOON ${ }^{\mathrm{TM}}$, Rescue Balloon ${ }^{\circledR} や$ Rescue Balloon ${ }^{\circledR}$-ERがもっともよく用いられ，後 者 2 つは 7fr シースに対応しており，諸外国で用い られる多くの REBOA カテーテルよりも小さい. REBOA の major 合併症のひとつである下肢の虚血 のリスクを軽減し, 挿入に要する時間や成功率を改 善し，また血管径の問題から挿入できなかった太い

済生会宇都宮病院救急 - 集中治療科 栃木県救命救急センター 于321-0974 栃木県宇都宮市竹林町 911-1

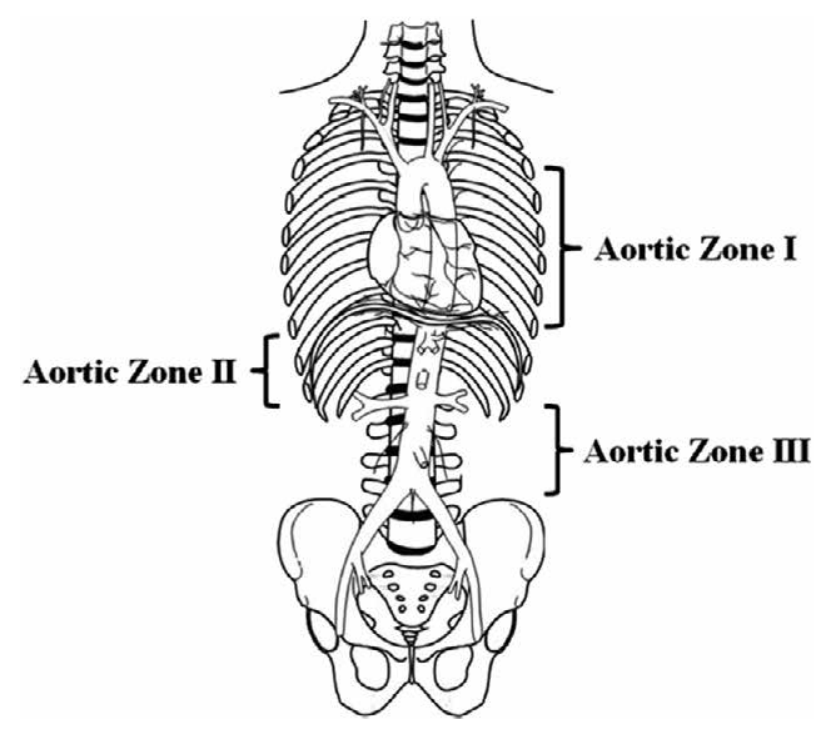

図 1 Aortic Zone (文献 ${ }^{9)}$ より引用)

シースが挿入困難な症例にも適応できるようになっ た。また， REBOAカテーテルは原則ガイドワイ ヤーを用いて留置することとなっているが，ERREBOA カテーテルは先端が pigtail 状になってお り，ワイヤーを用いずにカテーテルの留置が可能と なっている，現時点で本邦での使用は制限されてい るが，より小径で迅速に留置できるカテーテルが, 世界的にも主流になりつつある。

\section{III 留置位置}

大動脈を 3 つのZone に区分して, 出血源により balloon occlusionする位置を決定する.Z Zone1は， 左鎖骨下動脈から腹腔動脈までの領域, Zone2 は腹 腔動脈から腎動脈までの領域, Zone3 は腎動脈から 大動脈分岐部までの領域である(図 1).Zone2 は, Zone3 と比して付加的な効果がないのに加え て, 臓器虚血のリスクを高めるため, この領域での 
balloon inflation は通常行わない1)。出血源がおおよ そ同定できる場合は, 腹腔内の出血に関しては Zone1を, 骨盤骨折や婦人科系臓器の出血に関して はZ Zone3 を選択する ${ }^{2)}$. 血管造影室では最も安全に 留置できるが，ERや手術室でもCアームを用いる ことができれば,リアルタイムで透視下に, 目標と しているZoneへの留置を確認することができる. レントゲンで最終的な位置を確認できる場合には, Zone1は, balloonが横隔膜を超える位置に，また Zone3 は balloon が L2-3 を目安に留置する。また, これらのツールが使用できない状況下では，体表に REBOA カテーテルを添えることで，おおよその指 標になりえる。岡田らの報告によると ${ }^{19)}$, 胸骨上縁 と剣状突起をメルクマールとすることで, Zone1へ の留置が安全に行えることを示した。またPezy ら の報告によると, 280 人の外傷患者（身長平均值 $170.7 \mathrm{~cm})$ を後方視的に観察した研究で, Zone I は 両側の femoral artery から 414-474 mm の距離に,

Zone III は236-256 mmの距離にそれぞれ 99.6\% , 97.9\%の確率で存在することを示した ${ }^{15)}$. 解剖学的メルクマールを用いることで, REBOA は $\mathrm{ER}$ 手術室, 病院前と透視環境がない環境での迅 速な挿入が可能となる。

また， balloonの留置位置は，単に出血位置のみ ならず, 患者の循環動態やその後の治療戦略でも変 わる。動物実験で, Zone3 REBOAは, 不要な臓器 虚血を避けることができる一方で, proximal 側の 血行動態へ及ぼす影響は小さいことが示されてい る ${ }^{3)}$. 実際, AORTA データベースを解析した研究 では, balloonの位置の違いによる proximal 側の血 圧を比較している.Zone1 REBOA と Zone3 REBOA では, 初期の血圧, 意識レベル, 外傷の重症度は差 がないが, Zone1 REBOA 群で proximal 側の優位な 血圧上昇があった（58 $\pm 4 \mathrm{mmHg}$ vs $41 \pm 4 \mathrm{mmHg}$, $\mathrm{P}=0.008)^{4)}$. 比較的血行動態の安定している状況 下でZone3 選択することは reasonableである が，血行動態が破綻している状況下では, より強力 な proximal 側の循環サポートが可能なZone1 REBOA が有効である。

balloon の inflation volume は, カテーテルごとに 最大值が定められている一方で，適切な volume は 患者と状況により異なる。過剰な inflationによる血 管損傷を防ぐために, femoral artery の動脈圧・脈 圧の変化を観察することは有用である（詳細は 【REBOAの有害事象】を参照).

\section{IV 外傷に対するREBOA}

出血は外傷における主たる死因であり, 出血の管 理が外傷死を減らすために必須であることは自明で ある。蘇生的開胸術 (Resuscitative thoracotomy; RT）は，大動脈遮断を行うことで近位側の還流を 保ちつつ, 肺および心臓に対する速やかな止血操作 が可能となるために，循環動態が不安定な外傷患者 に対して行われてきた。これによって，胸部鋭的損 傷で $20 \%$ の生存率が得られた一方で, 腹部外傷で は $5 \%$ に満たない23). 胸部外傷に対しては，特に止 血操作を十分に行っていない状況下では, Zone1, 3への REBOA 留置は出血を助長するために行うべ きはない.また，大動脈損傷が疑える症例に関して も, REBOA は相対的禁忌となる。しかし, 腹部外 傷に対する RT と大動脈遮断は，出血部位に対する 止血操作が同時に行えないデメリットがあり，

REBOA はRTに比して低侵襲であり, 同時に出血 源への止血操作を行える点では優位である.

横隔膜下の出血に対しては, 外傷初期診療の中で 超音波 (FAST ; Focused Assessment with Sonography for Trauma）やレントゲン検査所見を合わせる ことで，その留置位置を決定する（図2）。横隔膜 下への出血はZone1，また骨盤骨折や bifurcation 以遠の出血に対してはZone3を選択する. FAST negative（モリソン窩，脾臓周囲，骨盤腔内にエ コーフリースペースが確認できない）で，レントゲ ンで骨盤骨折が明らかでない場合は, 後腹膜や各臓 器被膜内への出血や管腔内への出血を考え, Zone1 への留置を行う. 小倉らは, CT 施行前に外傷初期 診療において腹腔内実質臓器損傷を疑い, Zone I REBOAを用いた出血コントロールと輸血戦略によ る蘇生を行い, CTでの診断に引き続き血管内治療 を行うことで，手術を行わずに $80 \%$ 超の生存率を 得られたことを報告している ${ }^{25)}$.

骨盤骨折では静脈叢からの出血が問題となること が少なくないが， REBOAによる動脈での血流コン トロールと固定具を用いた骨盤固定を併用すること で，凝固異常を立ち上げ循環動態を安定化すること ができる ${ }^{24)}$.

頭部外傷合併の外傷に対する REBOA は，慎重に 検討すべきである，正常脳は， autoregulation 機能 により体血圧によらず一定の脳還流を維持すること ができる。一方で, 重症頭部外傷では, その autoregulation 機能が破綻するため, REBOAによる近 位側の血圧上昇が，脳血流を上昇させることにより 出血を助長し, 凝固塊を破綻させ, 脳圧上昇につな がる可能性がある。また, balloon deflation 後の虚 


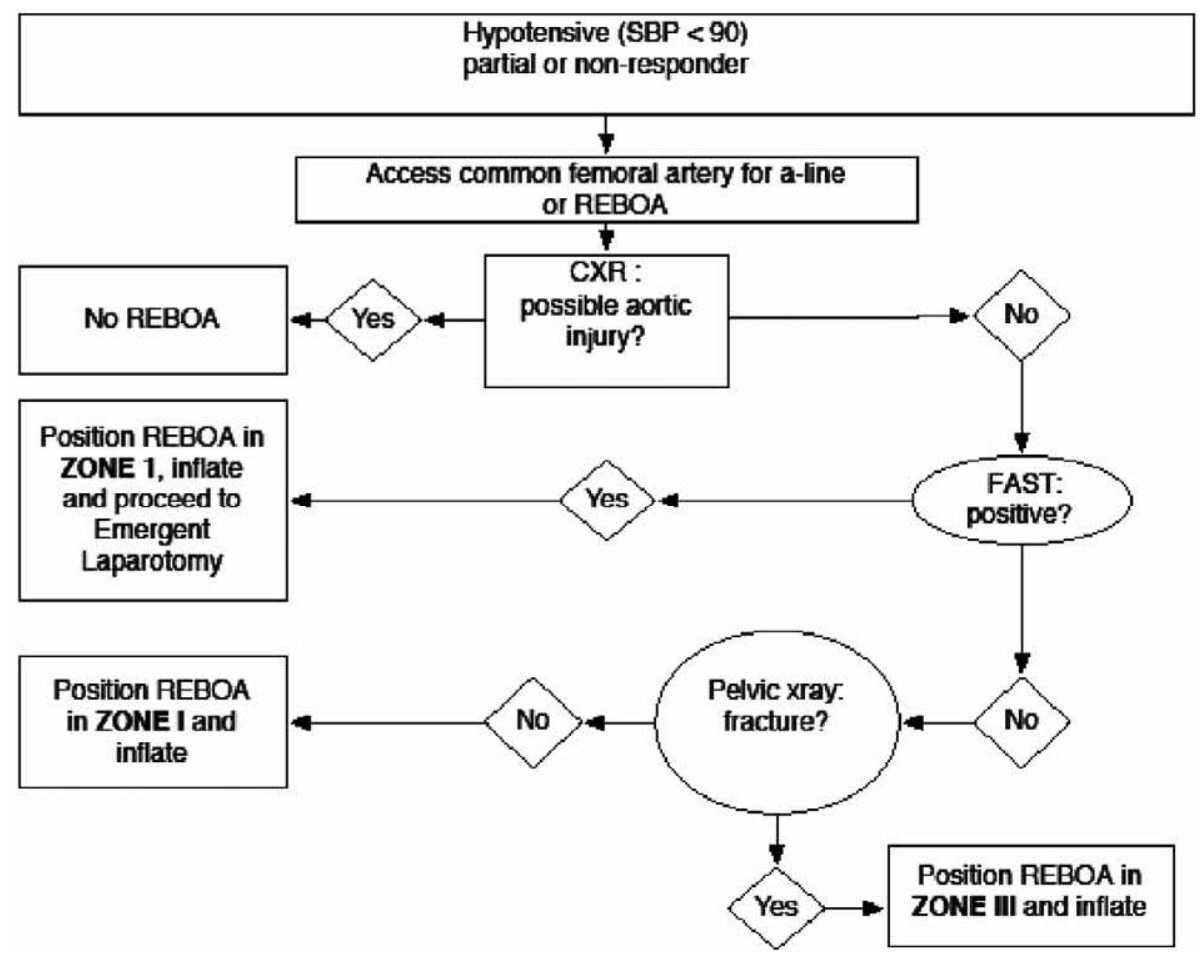

図 2 Journal of Trauma and Acute Care Surgery : August 2014-Volume 77-Issue 2-p 286291 より引用.

血再灌流障害による血管拡張，血圧低下も，2 次性 脳損傷につながる恐れがある ${ }^{21)}$ ，実際，REBOAを 用いて蘇生したのちに頭蓋内血種が増大したという 報告も多く，また日本の外傷データバンクを用いた 解析でも，より重度の頭部外傷合併群で死亡率が高 い結果となっていた ${ }^{22)}$ 。しかし一方で, 低血圧を避 け適切な脳還流を保つことは二次性脳損傷の回避に 不可欠であり, 頭部外傷合併の腹部 ·骨盤外傷に は，のちに述べる Partial REBOA を用いて近位側の 過剩な血圧上昇に十分注意をして管理をすること で, 有効である可能性がある. 現時点で, 多くのガ イドラインや expert opinion では，頭部外傷合併例 に関しては，REBOAを推奨しておらず，慎重に判 断すべきである。

外傷に打ける REBOA 挿入のタイミングはいつ か? 来院後すぐか, それとも CT 施行後か, もし くは手術室 / 血管造影室に入室後か? 松村らは, Injury Severity Score（ISS）に加え, 来院から動脈 のアクセスラインの確立までの時間が，30日生存 率と優位な相関をもつことを示した ${ }^{7)}$. 外傷診療に おいて, 時間はもっとも意識しなくてはならない要 素のひとつである，重症外傷を $3 つ$ phase - Primary survey, CT, damage control interventional radiology（DCIR）一で考え，すべてのPhaseにお いて “Start soon and finish sooner”を原則とした PRESTO protocol (Prompt and Rapid Endovascular
Strategies in Trauma Occasions）を提唱した松本ら は, 動脈へのシース確保は Primary surveyの中で 行うこととしている ${ }^{8)}$. ERでの Primary surveyに 続く CT や手術室 / 血管造影室への移動時や, decision making の間の出血コントロールのための REBOAのアクセスルートとしてのみならず, モニ タリングや輸血ラインともなりうるので, 早い段階 でのライン確保は reasonable である.

EndoVascular and Hybrid Trauma Management （EVTM）は，持続する外傷に対する出血に対し て，早急に REBOA や塞栓術，ステントグラフトを 用いた治療介入を行うというコンセプトである。循 環動態不安定な腹部鈍的外傷患者に，REBOAによ る早期の hemodynamic support のもと，CTに続き 迅速な塞栓術行うことで，手術を行うことなく止血 を得，80\%の生存率を達成したという報告もあ る ${ }^{17)}$. Romagnoli A らは, 外傷センターでの検討の 中で, REBOA と RT の大動脈遮断に要する時間を 比較しているが, femoral arteryへのアクセスルー トがすでに留置されている状況下では，REBOAの ほうが早いと報告している ${ }^{18)}$. Femoral arteryは, 循環が破綻もしくは CPA になるとエコーガイド下 でも血管穿刺が困難となる。特に, 循環動態が不安 定な major traumaの症例では, 必要時に迅速に REBOAを可能とするよう, 早期に $5 \mathrm{Fr}$ シースを導 入しておくことも検討すべきである ${ }^{16)}$. 


\section{$\mathrm{V}$ 外傷以外への REBOA の適応}

上部消化管や破裂動脈瘤による大量出血が主な原 因の出血性ショックへの REBOAの効果を米国の tertiary care center 単施設で検討している. CPA も しくは near CPAの場合は, Zone1への留置, non responderの出血性ショックには骨盤腔内であれば Zone3, 腹腔内であればZone1への留置を行った。 REBOA 留置前にCPAにいたっていた患者が $64 \%$ いたにもかかわらず，60\%を超える生存率であった と報告している。非外傷性疾患に対する REBOAの 可能性を示唆した ${ }^{12)}$.

特に, 産科出血に対する REBOAの使用に関して は，近年多くの報告がある。周産期の死亡の原因と して出血はもっとも多く, REBOAの使用により出 血量をコントロールすることができる，大量出血が 予測されるハイリスク患者（楔入胎盤，穿通胎盤， 前置胎盤などの胎盤異常）に対する予防的な使用， また術中もしくは術後の導入により危機的出血を回 避できる可能性がある。通常, 子宮や骨盤骨折によ る出血のコントロールには, Zone 3 REBOA が選択 されることが多いが, Zone3 REBOA では, 卵巣動 脈の閉塞はできない. しかし, 前置胎盤合併の選択 的帝王切開に対する Zone3 REBOAの予防的使用に 関する systematic review では, 出血量の減少, 輸 血量の減少に寄与したとしている，REBOAに関す る有害事象もなく, 致死的な産後出血のリスクがあ る患者の予後改善に有効である可能性を示した ${ }^{13)}$. 帝王切開中の胎盤異常を伴う妊婦に対して, 予防的 もしくは出血コントロールとしてREBOA を使用す ることは，実現可能な有効で安全な手段である ${ }^{14)}$.

また, 致死率が非常に高い腹部大動脈瘤破裂に対 しても，その有効性を示す報告が多くある. REBOA は, 来院時重度の循環不全をきたしている 患者であっても, 速やかかつ安全に循環を立ち上げ 維持することで, Endovascular Aneurysm Repair (EVAR) もしくは Open Aortic Repair (OAR) の治 療を可能にする ${ }^{26)}$. Mehta らは ${ }^{27)}$, 腹部大動脈瘤 破裂に対する EVAR施行時の REBOAを, femoral artery から挿入することのメリットとして次の 3 つ をあげている；1. 頭元の蘇生チームと干渉しない (静脈ライン確保など), 2. 循環虚脱している患者で あっても比較的容易にアクセスできる， 3. 太いシー スが必要な際に, brachial arteryは合併症が多く外 科的な処置が必要となる。また, Abdominal Compartment Syndromeの発生が, 予後不良因子である ことが知られており, 動脈瘤破裂の早期の診断と出 血制御が重要である. Definitive 治療までの出血制
御に REBOA は有効であり, 早期のアクセスルート 確保を含む治療ストラテジー構築が, 予後改善につ ながると考えられる ${ }^{27)}$.

\section{REBOA の有害事象}

REBOAの留置時には, 大動脈弓部やZ Zone II へ の意図しない留置などの位置異常や, 刺入部や大動 脈解離, 穿通枝への迷入などによる血管損傷, balloon occlusion による臟器虚血などさまざまである.

位置異常は, 先に述べたように, REBOAを血管 造影室で留置することで避けうる，血管造影室で は, balloonの inflation が正常に行えているかどう かなど、しかし, ERでの重症外傷診療時や, 手術 室での術中の大量出血時は，かならずしもそれが可 能とは限らない. 胸腹部ポータブルレントゲン検査 や，Cアームを使用して代用することも可能であ る.

小倉らは, エコーと, 左手および鼠径部のシース で測定する血圧から，不適切な留意位置や過剩な balloon inflation を防ぐことができるとしている9 (図 3). 腹部エコーにより腹部大動脈を描出し, balloon がZone2 を超えたことを確認する。次に， 胸部大動脈は経胸壁心エコーでは描出困難であるの で, balloon が大動脈弓部にかからないことを, 左 手の血圧より推定する。つまり, balloon inflation 時に左手の血圧が低下すればそれは balloon が大動 脈弓部に位置していることを意味する。また，対側 femoral arteryのシースで血圧をモニタリングする ことで, balloonの over inflation を防ぐことができ る. balloonを徐々に inflationするにつれ，下肢の 血圧波形は脈圧が減少し最終的に平坦になる。この 時点が，REBOAにより末梢側の血流を遮断できた 瞬間である。また，エコーは低血圧時に刺入部とな る鼠径部で拍動が触れづらい際にも, 穿刺を容易に するため，穿刺に費やす時間の節約や穿刺部合併症 の軽減にもつながる。

また，長時間の balloon inflationは，末梢側での 臓器虚血一再灌流障害や死亡率上昇と相関があると される ${ }^{10)}$. かねがね occlusion timeは 30 分以内に とどめるべきであり，40６0 分以上の occlusion は, 臓器障害や死亡のリスクとなる。一方で, balloon は inflation 時のみならず，炎症性メディエー ターの放出, 塞栓, 代謝性アシドーシスや損傷部位 からの再出血など deflation 時にも有害事象を起こ しうる。これら REBOAの有害事象が患者に与える 影響は，施設ごとの技術や戦略，管理によって異な る ${ }^{11)}$ ，習熟することにより，REBOAの有害事象は 

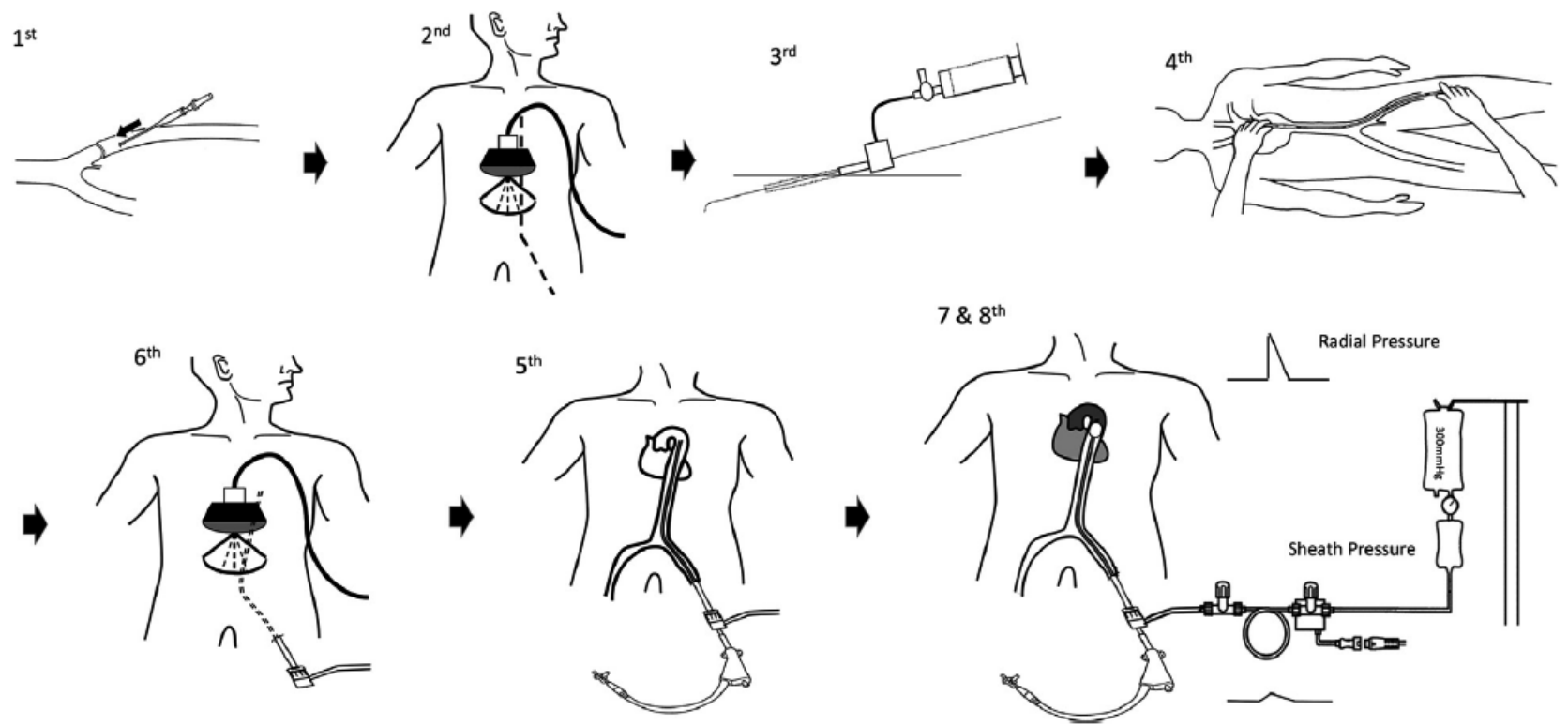

Step-by-step procedure for resuscitative endovascular balloon occlusion of the aorta.

図 3 文献 ${ }^{9)}$ より引用

そのメリットに比して許容できる程度に抑えること ができる。

VII Partial REBOA (P-REBOA) と Intermittent REBOA (I-REBOA)

REBOA は, 特にショックのような低循環時に, 脳や心臓, 肺などの主要藏器への血流を増やし, 循 環を維持することが可能である，一方で，血流遮断 部以遠の臓器虚血を血流再開時の再灌流障害は軽視 できない，Partial REBOA（P-REBOA）は，字のご とく“部分的な”大動脈遮断である. P-REBOA は，持続する損傷部位からの出血に対する出血コン トロールは, 完全遮断に劣る。しかし, 止血術を並 行して行うことで, この出血は許容されうるもので ある、P-REBOAによる近位側の低血圧は, 外傷一 般論の permissive hypotension の概念により許容さ れ，遮断部位以遠の虚血を相対的に軽減し，また同 時に近位側の高血圧と心臓の後負荷をも軽減するこ とも踏まえると, reasonableな戦術といえる. PREBOA は，大動脈遮断の程度を部分的に行う一方 で, Intermittent REBOA（I-REBOA）は完全 inflation/deflationを交互に行う。Kuckelmanらは, 致 死的腹部実質臓器損傷モデルにおいて，I-REBOA が full（完全遮断）REBOAよりも優位に出血量を 減らし, 虚血再灌流障害を最小限に抑え生存率を改 善するとしている ${ }^{20)}$. P-REBOA と I-REBOAはと もに, REBOAの合併症を軽減する手段ではある が，止血術が完了しておらず凝固障害をきたしてい る中での強度不十分な凝血が, full deflationにより
破綻してしまうリスクがあることを踏まえると， P-REBOA はその点でも有用かもしれない. PREBOA は，その有用性が多く報告されているが, わずかな balloon volume の変化が血行動態に与え る変化が大きく, 遠位側へ一定の低流量の血流を維 持するためには頻回の balloon volume の調整が必 要となり, 施行には修練が必要である.

\section{VIII 病院前での REBOA の使用}

Reynold らは, Level I Trauma center に搬送され た外傷性 CPAの患者から，病院前で REBOA（Prehospital REBOA）が有効であった患者群 $=$ 「重症頭 部外傷を合併していない腹腔内臓器損傷もしくは骨 盤骨折の患者」を後方視的に検証している ${ }^{5)}$. 現場 での Glasgow Coma Scale score $\geqq 9, \quad \mathrm{SpO} 2>90 \%$, 収縮期血圧 $<90 \mathrm{mmHg}$ が有意に Prehospital REBOA 有効である因子であった。 また，外傷性 CPA 患者の $10 \%$ 以上が Prehospital REBOA が有効 である可能性を指摘している.

また，現場でREBOAを挿入することによる， Trauma centerへの搬送遅延, 強いては根治的治療 への遅延にもつながりうる。しかし, 持続する出血 やこれに対する細胞外液輸液は, deadly triadのひ とつである凝固異常を助長し, 続いて起こる代謝性 アシドーシスや低体温を併発し deadly triad が完成 してしまえば，救命は困難になる。また，ひとたび CPAに陥ってしまうと救命率が格段と下がること からも, 病院前で心停止を回避することには十分な 意義がある. Moore LJらは，REBOAにより，外 
傷による心肺停止患者の $60 \%$ が自己心拍再開を 得，また手術室入室前の出血による心停止を回避さ せることができる可能性を示した ${ }^{6)}$ 。腹腔内臓器損 傷，骨盤骨折による出血性ショックの患者の一時的 な出血コントロールとして, Prehospital REBOAが 有用な可能性がある。

一方で, REBOAにより出血量増大, 原疾患増悪 する可能性のある外傷性大動脈損傷・解離をはじめ とする胸部外傷の除外が難しいケースもあり, Prehospital REBOAの適応は今後も十分な検討が必要 である。

\section{X おわりに}

外傷の resuscitative toolとして使われてきた REBOA は今日, 非外傷性疾患を含むさまざまな出 血源の “hemorrhage control” tool として, ER, 手 術室, 血管造影室, 病院外などさまざまなシチュ エーションで用いられるようになった. Definitive 治療へのブリッジとして有用である一方で，その有 害事象も決して無視はできない. しかし，十分な知 識と経験をもってすれば, リスクは最小限に抑える ことができ，REBOAの有用性を高めることができ るであろう。

\section{文献}

1) Pezy P, Flaris AN, Prat NJ et al. : Fixed-distance model for balloon placement during fluoroscopy-free resuscitative endovascular balloon occlusion of the aorta in a civilian population. JAMA Surg $152: 351-358,2017$

2) Tsurukiri J, Akamine I, Sato T et al. : Resuscitative endovascular balloon occlusion of the aorta for uncontrolled haemorrahgic shock as an adjunct to haemostatic procedures in the acute care setting. Scand J Trauma Resusc Emerg Med 24: 72, 2016

3) Tibbits EM, Hoareau GL, Simon MA et al. : Location is everything: The hemodynamic effects of REBOA in Zone 1 versus Zone 3 of the aorta. J Trauma Acute Care Surg 85 : 101-107, 2018

4) Beyer CA, Johnson MA, Galante JM et al. : Zones matter : Hemodynamic effects of zone 1 vs zone 3 resuscitative endovascular balloon occlusion of the aorta placement in trauma patients. Injury $50: 855-858,2019$

5) Henry R, Matsushima K, Henry RN et al. : Who Would Have Benefited from the Prehospital Use of Resuscitative Endovascular Balloon Occlusion of the Aorta (REBOA) ? An Autopsy Study. J Am Coll Surg 229 : 383388, 2019

6) Moore LJ, Martin CD, Harvin JA et al. : Resuscitative endovascular balloon occlusion of the aorta for control of noncompressible truncal hemorrhage in the abdomen and pelvis. Am J Surg 212 : 1222-1230, 2016

7) Matsumura Y, Matsumoto J, Kondo H et al. : Early arterial access for resuscitative endovascular balloon occlusion of the aorta is related to survival outcome in trauma. J Trauma Acute Care Surg 85 : 507-511, 2018

8) Matsumoto J, Lohman BD, Morimoto K et al. : Damage control interventional radiology (DCIR) in prompt and rapid endovascularstrategies in trauma occasions (PRESTO) : A new paradigm. Diagn Interv Imaging 96 : 687691,2015

9) Ogura T, Lefor AK, Nakamura M et al. : UltrasoundGuided Resuscitative Endovascular Balloon Occlusion of the Aorta in the Resuscitation Area. J Emerg Med 52 : 715-722, 2017

10) Ribeiro Júnior MAF, Brenner M, Nguyen ATM et al. : Resuscitative endovascular balloon occlusion of the aorta (REBOA) : an updated review. Rev Col Bras Cir 45 : e1709, 2018

11) White JM, Cannon JW, Stannard A et al. : Endovascular balloon occlusion of the aorta is superior to resuscitative thoracotomy with aortic clamping in a porcine model of hemorrhagic shock. Surgery 150 : 400-409, 2011

12) Hoehn MR, Hansraj NZ, Pasley AM et al. : Resuscitative endovascular balloon occlusion of the aorta for non-traumatic intra-abdominal hemorrhage. Eur J Trauma Emerg Surg $45:$ 713-718, 2019

13) Ordoñez CA, Manzano-Nunez R, Parra MW et al. : Prophylactic use of resuscitative endovascular balloon occlusion of the aorta in women with abnormal placentation : a systematic review, meta-analysis, and case series. J Trauma Acute Care Surg 84 : 809-818, 2018

14) Manzano-Nunez R, Escobar-Vidarte MF, Naranjo MP et al. : Expanding the field of acute care surgery : a systematic review of the use of resuscitative endovascular balloon occlusion of the aorta (REBOA) in cases of morbidly adherent placenta. Eur J Trauma Emerg Surg 44 : 519-526, 2018

15) Pezy P, Flaris AN, Prat NJ et al. : Fixed-Distance Model for Balloon Placement During Fluoroscopy-Free Resuscitative Endovascular Balloon Occlusion of the Aorta in a Civilian Population. JAMA Surg 152 : 351-358, 2017

16) Coccolini F, Stahel PF, Montori et al. : Pelvic trauma : WSES classification and guidelines. World J Emerg Surg12 : 5, 2017

17) Ogura T, Lefor AT, Nakano $M$ et al. : Nonoperative management of hemodynamically unstable abdominal trauma patients with angioembolization and resuscitative endovascular balloon occlusion of the aorta. J Trauma Acute Care Surg 78 : 132-135, 2015

18) Romagnoli A, Teeter W, Pasley J et al. : Time to aortic occlusion : It's all about access. J Trauma Acute Care Surg $83: 1161-1164,2017$ 
19) Okada $\mathrm{Y}$, Narumiya H, Ishi W et al. : Anatomical landmarks for safely implementing resuscitative balloon occlusion of the aorta (REBOA) in zone 1 without fluoroscopy. Scand J Trauma Resusc Emerg Med 25 : 63, 2017

20) Kuckelman J, Derickson M, Barron M et al. : Efficacy of intermittent versus standard resuscitative endovascular balloon occlusion of the aorta in a lethal solid organ injury model. J Trauma Acute Care Surg 87 : 9-17, 2019

21) Hörer T, DuBose JJ, Rasmussen $T$ et al. : Endovascular Resuscitation and Trauma Management, Sprnger, Berlin, 2020

22) Norii T, Crandall C, Terasaka Y : Survival of severe blunt trauma patients treated with resuscitative endovascular balloon occlusion of the aorta compared with propensity score-adjusted untreated patients. J Trauma Acute Care Surg $78:$ 721-728, 2015

23) Brenner ML, Moore LJ, DuBose JJ et al. : A clinical series of resuscitative endovascular balloon occlusion of the aorta for hemorrhage control and resuscitation. J Trauma
Acute Care Surg 75 : 506-511, 2013

24) Brenner M, Teeter W, Hoehn M et al. : Use of Resuscitative Endovascular Balloon Occlusion of the Aorta for Proximal Aortic Control in Patients With Severe Hemorrhage and Arrest. JAMA Surg $153:$ 130-135, 2018

25) Ogura T, Lefor AT, Nakano $\mathrm{M}$ et al. : Nonoperative management of hemodynamically unstable abdominal trauma patients with angioembolization and resuscitative endovascular balloon occlusion of the aorta. J Trauma Acute Care Surg 8 : 132-135, 2015

26) Bath J, Leite JO, Rahimi M et al. : Contemporary outcomes for ruptured abdominal aortic aneurysms using endovascular balloon control for hypotension. J Vasc Surg 67 : 1389-1396, 2018

27) Mehta M, Paty PS, Byrne J et al. : The impact of hemodynamic status on outcomes of endovascular abdominal aortic aneurysm repair for rupture. J Vasc Surg 57 : 1255-1260, 2013 